Ethiopian Journal of Environmental Studies \& Management 8(6): 616 - 627, 2015.

ISSN:1998-0507

doi: http://dx.doi.org/10.4314/ejesm.v8i6.1

Submitted: November 07, 2014

Accepted: August 06, 2015

\title{
A GIS-BASED FLOOD RISK MAPPING ALONG THE NIGER-BENUE RIVER BASIN IN NIGERIA USING WATERSHED APPROACH
}

*AKINBOBOLA, A., OKOGBUE, E.C. AND OLAJIIRE, 0.0.

Department of Meteorology and Climate Science, Federal University of Technology, Akure, Ondo State, Nigeria

\begin{abstract}
Floods are water induced disasters that lead to temporary inundation of dry land and cause serious damages in the affected location such as loss of lives and properties and destruction of infrastructures. They have become common occurrences in every part Nigeria and the recorded impacts of flooding on the inhabitants are alarming, causing hundreds of deaths and rendering thousands homeless. The impact of floods on people globally has led to the development of mitigation measures that could reduce the associated risk of floods to a manageable point. The management of flood risk begins with identification of areas prone to flood. This study used the scientific technique of GIS to identify flood risk areas along the River Niger-Benue basin. Satellite imageries SRTM DEM that covers the study area was used in this research. Monthly rainfall data was used to generate maps of standardized precipitation index (SPI) for thirty years (1978 to 2007). The SPI maps were used to determine the degree of precipitation condition across Nigeria and also to identify the locations where flood events are being triggered. The SRTM DEM was used to generate the flow direction and flow accumulation maps. Flow direction and Flow accumulation were used to generate the watershed and flood risk map. The flood risk map shows that 45\% of Nigeria towns and villages are within the flood risk zone. Finally, some recommendations were made which will help the policy makers improve on flood management in the country.
\end{abstract}

Key Words: Flood, Flood risk, Flow direction, Satellite imagery

\section{Introduction}

Floods are an extreme naturally occurring weather event that results in an overflowing of large amounts of surface water over land that is not always inundated (Adeoye et al., 2009). It is considered to be the worst natural disaster in the world and it is responsible for a third of all natural problems and half of damages on facilities around the globe. It has become one of the most frequent natural occurrences in the last few decades (Jeb and Aggarwal, 2008).
Floods have cost damages to societies totalling more than 250 billion dollars and the intensity and frequency of floods are increasing globally. It is gradually becoming a common phenomenon around the world, caused by increase in global temperatures that result in torrential rains and rise in sea level that overflowed their banks and flood surrounding coastal lands (Jeb and Aggarwal, 2008). In Nigeria, aside from droughts, floods cause almost 90 percent of damages resulting from natural

*Corresponding author: Akinbobola, A.

Email: desmondbobola@yahoo.com 
hazards (Adeoye et al., 2009). Floods that occur in Nigeria are as a result of extensive rainfall, drainage blockages and dam failures (Jeb and Aggarwal, 2008). The effect of floods in Nigeria has been on the increase especially in the last three decades. It has become a life threatening concern to the citizenry and the number of deaths and damages caused by this perennial disaster are alarming. Annually, more than 700,000 hectares of arable land and built up areas are damaged due to flooding in Nigeria (Jeb and Aggarwal, 2008). Recorded damages include destruction of schools, houses built with mud brick and other traditional building materials, bridges, markets and washing away of agricultural lands (Adeoye et al., 2009). Nigeria recorded its first flood in 1948 in Ibadan, capital of Oyo State. Since then, the menace has spread like wild fire to other states of the federation. More than half of the thirtysix states in Nigeria have been hit by one form of flood or another (Adeoye et al., 2009) that occur along the Rivers Niger and Benue (Jeb and Aggarwal, 2008). Some of the states that have been badly hit by floods in the country include Kano, Niger, Jigawa, Kaduna, Adamawa, Benue, Kogi and many others in the southern parts of Nigeria (Adeoye et al., 2009; Jeb and Aggarwal, 2008). In August 2001, thousands of people were displaced in Kano and Jigawa States as a result of flood that was caused by the overflowing of rivers Challawa and Kano. Twenty people were reported dead in Kano while 180 others were reported dead in Jigawa state (Jeb and Aggarwal, 2008). A record of the total number of people affected by the flood incidence was well above 143,000 (Jeb and Aggarwal, 2008). Four years later, precisely in August, 2005, the worst floods in forty years occurred in the northern city of Jalingo, the capital of Taraba state, after a heavy down pour of rain that lasted for eight hours (Jeb and Aggarwal, 2008). Over 100 people were killed in the event and thousands of others displaced. Similar incidence occurred in Zamfara state in September, 2006, when a torrential rainfall that lasted for 24 hours caused the collapse of a dam located outside the state's capital Gusau. The dam failure led to an influx of water into the nearby villages washing away hundreds of houses and destroying property worth millions of dollars (Jeb and Aggarwal, 2008). The exceptionally heavy rainfall of August 2007 in Nigeria led to more than 46 deaths and displacement of over 2,500 families. The nine states that were seriously affected were Lagos, Ogun, Plateau, Nassarawa, Bauchi, Sokoto, Yobe, Borno and Kebbi. The floods were caused by poor drainage systems, ill-timed discharge of water from dams and the indiscriminate infrastructural development along river banks (IFRC, 2008). In 2010, dam failures as well as opening of flood gates and torrential rains all contributed to flooding in some northern states in Nigeria. Over 2 million people and 5,000 villages were affected and about 50,000 families were left homeless (NASA, 2011f; CBS, 2010; Aljazeera, 2010). Most recently in 2011, at least 102 deaths were recorded and 2,000 families were displaced in and around the south-western city of Ibadan as a result of floods from heavy rainfall that collapsed bridges and caused a dam to overflow (BBC Mobile, 2011a; Aljazeera, 2011). In June, 2011, the ancient city of Kano experienced extensive rainfall which led to flooding in some parts of the city causing 24 deaths, collapse of houses and displacement of 700 people (Mukhtar, 2011; Nmeribeh, 2011).

The Federal Government of Nigeria has invested millions of dollars both on relief and compensation as well as rehabilitation of flooded areas yet the menace is still unabated (Jeb and Aggarwal, 2008). These 
days, flooding events are more rampant in urban cities in Nigeria than in the rural areas. It is fast becoming a serious environmental problem resulting in huge loss of lives, property and priceless arable land. Floods have rendered many people homeless and disrupted a lot of socioeconomic activities in urban cities. Various flood plains and land along the Atlantic Ocean coast are affected by flooding yearly in Nigeria (Jeb and Aggarwal, 2008).

The aim of this work is to identify towns and villages that are prone to floods along the Niger-Benue river basin and develop a GIS-based flood risk map that can be easily understood by the policy makers and public. This will facilitate proper planning of mitigation measures against future floods and this will be achieved by applying GIS techniques in the identification and mapping of flood plain along the Niger-Benue river basin using the watershed approach.

\section{Methodology}

Monthly rainfall data for 29 stations across Nigeria was collected from The Nigerian Meteorological Agency, Lagos office (NIMET). The geographical information system (GIS) shape files were gotten from digitized satellite imageries downloaded from the internet. Satellite imageries, SRTM to generate digital elevation model (DEM), for the study area were downloaded from Global Land Cover Facility site (glcf.umd.edu).

\section{Data Preparation}

The rainfall data was collated and arranged. The GIS vector shape files were kept in a single folder. This is because the shape files when opened in a folder are saved as different extensions. If any of the extension is missing in the folder, the shape file won't load in the GIS software.

Standard Precipitation Index (SPI)
The SPI is based on the probability of precipitation for any time scale. The probability of observed precipitation is then transformed into an index. The index is used to determine rainfall extremes. The SPI is after Tom et al 1993. The purpose is to assign a single numeric value to the precipitation which can be compared across regions with markedly different climates. Technically, the SPI is the number of standard deviations that the observed value would deviate from the long-term mean, for a normally distributed random variable. Since precipitation is not normally distributed, a transformation is first applied so that the transformed precipitation values follow a normal distribution.

The Standardized Precipitation Index was designed to explicitly express the fact that it is possible to simultaneously experience wet conditions on one or more time scales, and dry conditions at other time scales, often a difficult concept to convey in simple terms to decision-makers. Consequently, a separate SPI value is calculated for a selection of time scales, covering the last $1,2,3,4,5,6,7,8,9,10$, $11,12,15,18,24,30,36,48,60$, and 72 months, and ending on the last day of the latest month.

Table 1: SPI Values

\begin{tabular}{l|l}
\hline $2.0+$ & Extremely wet \\
1.5 to 1.99 & Very wet \\
1.0 to 1.49 & Moderately wet \\
-0.99 to 0.99 & Near normal \\
-1.0 to -1.49 & Moderately dry \\
-1.5 to -1.99 & Severely dry \\
-2 and less & Extremely dry \\
\hline
\end{tabular}

(Source: standard precipitation index user guide, WMO)

\section{Arcmap 9.2}

Arc map is GIS software that is used to analyse vector and raster data to produce a map. Arc map is used to produce geospatial maps of various locations on the earth. In 
this study arc map was used to do most of the analysis like 'select by location' and spatial analysis. This software will be used to produce the flood risk map.

\section{Spatial Analysis}

It is used to do a digital elevation model (DEM) to get the topology of area of study and also to show the SPI distribution across Nigeria. Contour analysis was done on the satellite imagery to extract the contour of the study area. Hillshade analysis was done to generate mountainous map of the study area. Interpolate to raster tool using inverse distance weighted is used to generate the spatial distribution of SPI across Nigeria. The spatial analyst hydrology tool is used to generate the flow direction, flow accumulation, pour point and watershed area.

\section{Watershed}

Watershed 'is the drainage area' that contributes run-off water to a drainage course or water body. It is also called a contributing area; this function identifies every contributing area through a series of points. The points can be selected from the pour points or intersections of the stream network that created before.

\section{Study Area}

Nigeria is geographically located downstream river Niger and Benue that takes their sources from Guinea and Cameroun respectively. Both rivers discharge into the country by forming a confluence at Lokoja. The Niger basin has a total active catchment area of about 1.5 million $\mathrm{km}^{2}$ and usually subdivided into the Upper Niger, Inland Delta, Middle Niger and the Lower Niger basins. Nigeria is located in the latter covering about $30 \%$ of the Niger basin total catchment area. River Niger is 4,200 km long, making it the third longest river in Africa and the 14th longest in the world. Its basin area of about $1.5 \mathrm{x}$ $106 \mathrm{~km}^{2}$ makes it the world's ninth largest river basin. The Niger basin covers 9 Countries of West and part of Central Africa in the following proportions; Benin (2\%), Burkina (4\%), Cameroun (4\%), Chad (1\%), Cote D'Ivoire (1\%), Guinea (6\%), Mali (25\%), Niger (21\%) and Nigeria $(32 \%)$.River Benue is located between Latitudes $7^{\circ} 13^{\prime} \mathrm{N}$ and $8^{\circ} 00^{\prime} \mathrm{N}$ and Longitudes $8^{\circ} 00^{\prime} \mathrm{E}$ and $9^{\circ} 00^{\prime} \mathrm{E}$ with a total basin area of $7685.28 \mathrm{~km}^{2}$. River Benue which rises from the Adamawa Plateau of Central Cameroon, then flows west across Central Nigeria, and joins River Niger at Lokoja, Kogi State. River Niger is located between Latitudes $11^{\circ} 40^{\prime} \mathrm{N}$ and $4^{\circ} 17^{\prime} \mathrm{N}$ and Longitude $3^{\circ} 37^{\prime} \mathrm{E}$ and $5^{\circ} 59^{\prime} \mathrm{E}$. There are 16 states on the Niger-Benue river basin which are: Kebbi, Adamawa, Niger, Kwara, Kogi, Taraba, Benue, Enugu, Nassarawa, Edo, Anambra, Imo, Delta, Bayelsa, Rivers, and Akwa Ibom.

\section{Results and Discussions}

\section{Variation of Standardized Precipitation Index}

Figures 1 (a-c) show the variation of standardized precipitation index across Nigeria for some selected year classifying them into six categories which are severely dry, moderately dry, near normal, moderately wet, very wet and extremely wet conditions. 
Ethiopian Journal of Environmental Studies and Management Vol. 8 no. 6, 2015

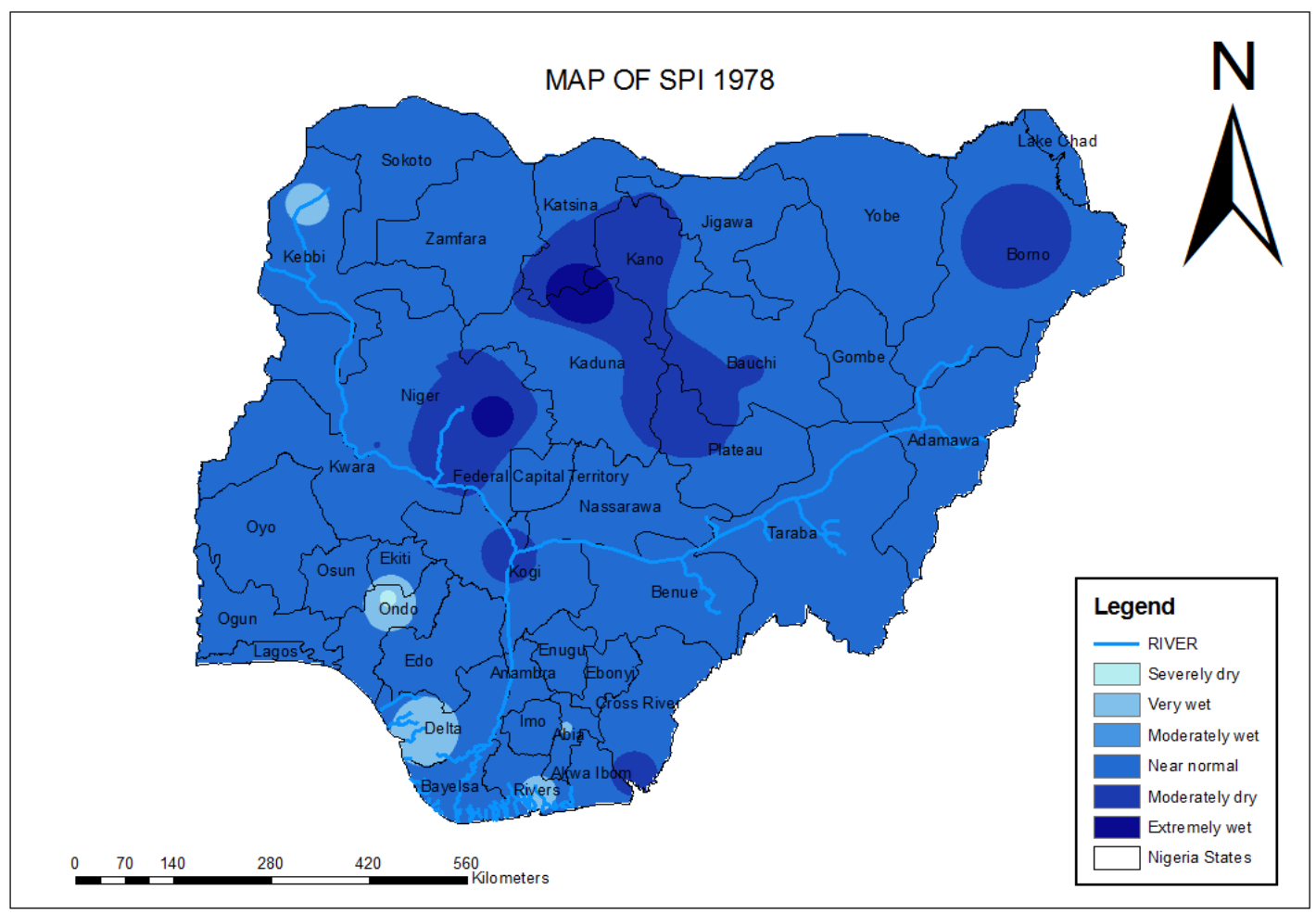

Fig. 1 a Map of SPI for 1978

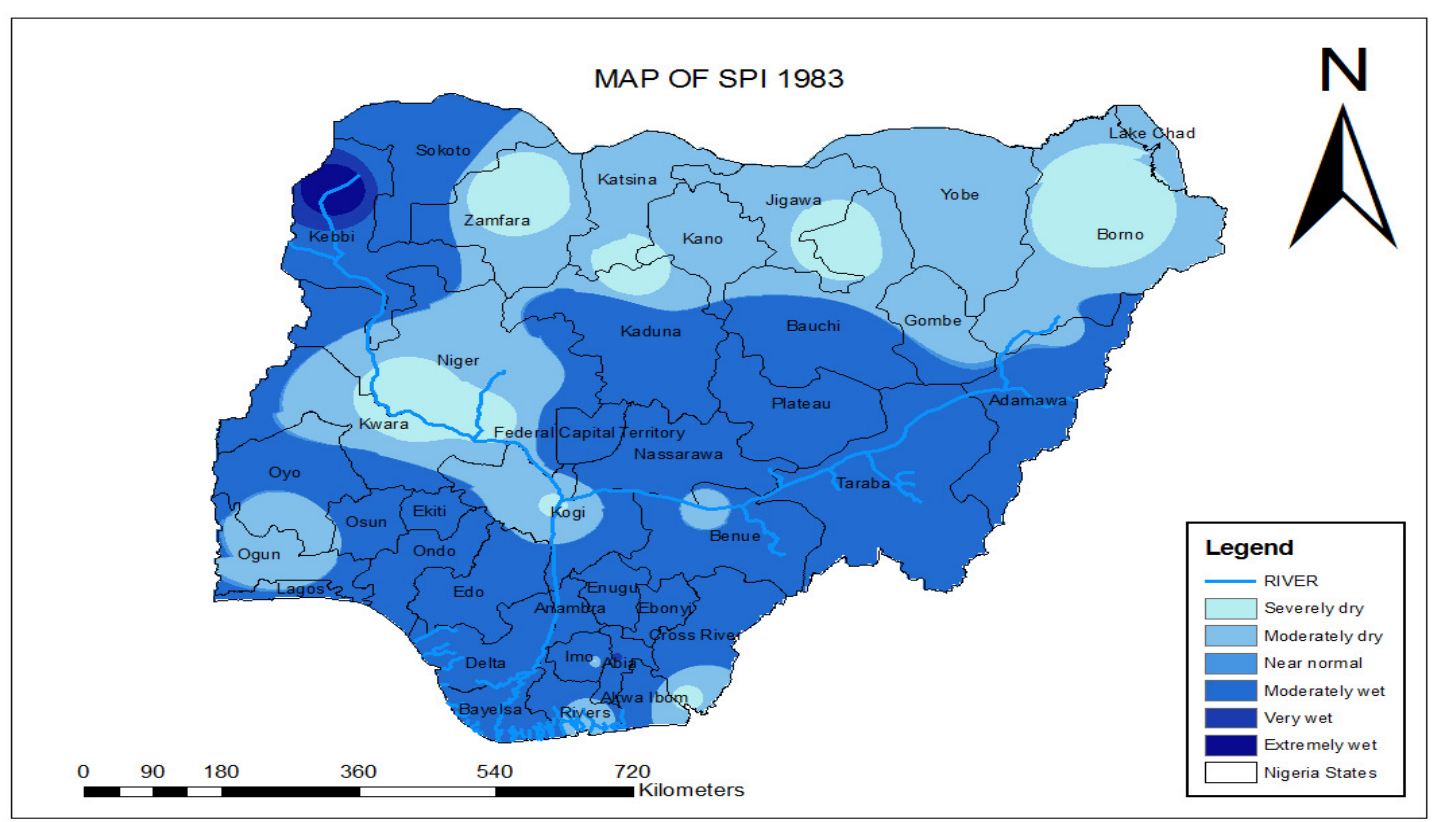

Fig. 1 (b) Map of SPI for 1983 


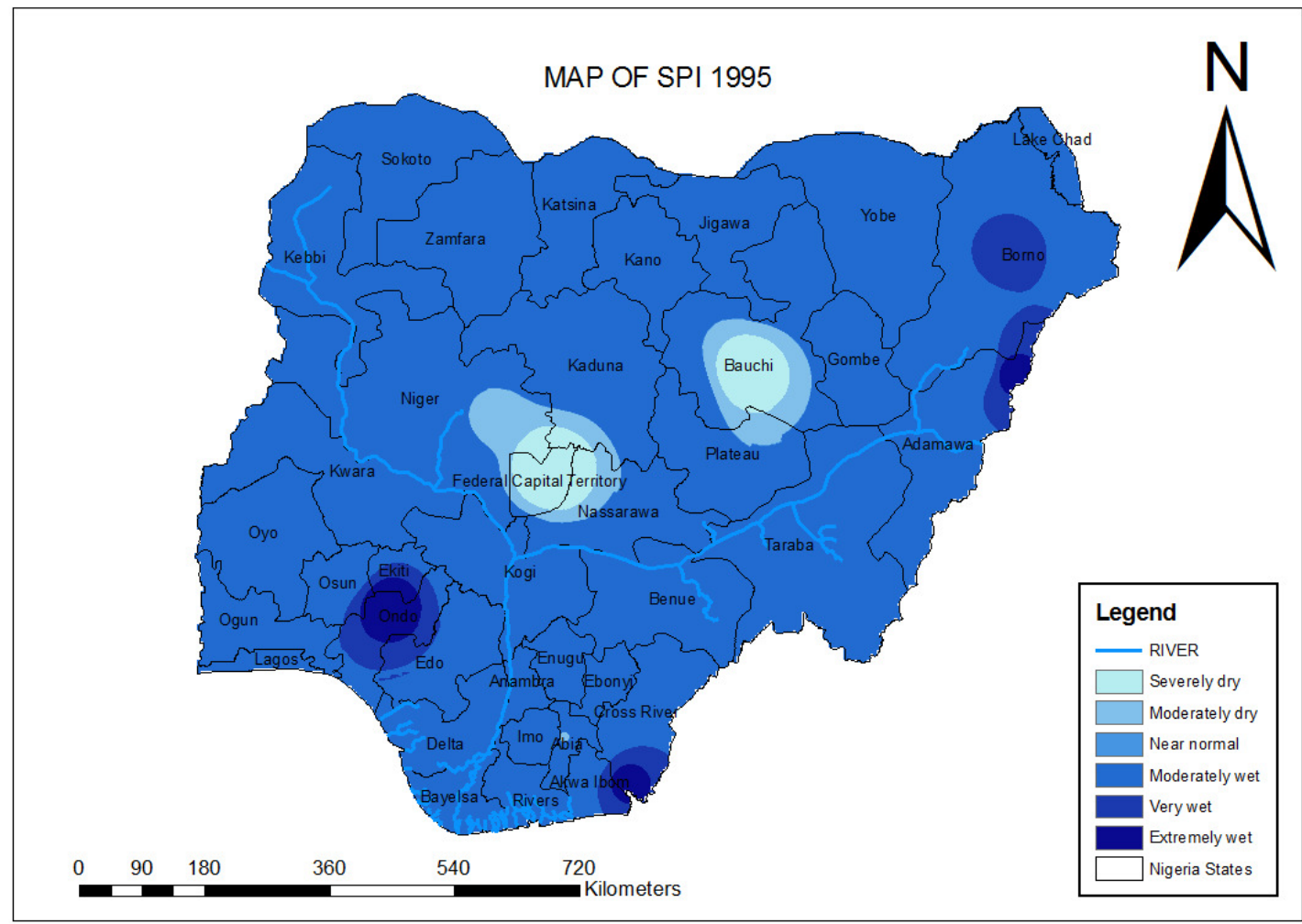

Fig. 1 (c) Map of SPI for 1995

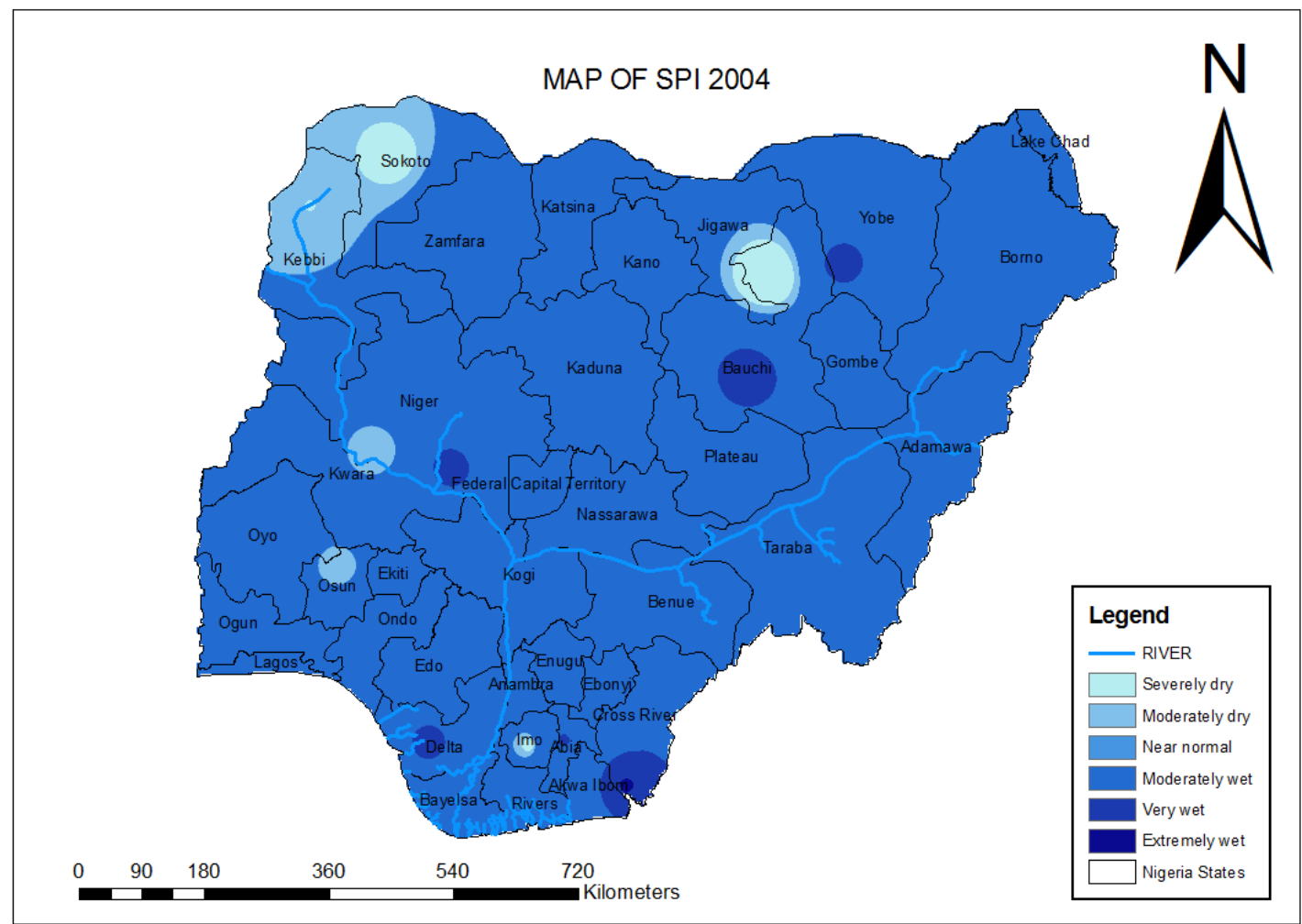

Fig. 1 (d) Map of SPI for 2004 
Ethiopian Journal of Environmental Studies and Management Vol. 8 no. 6, 2015

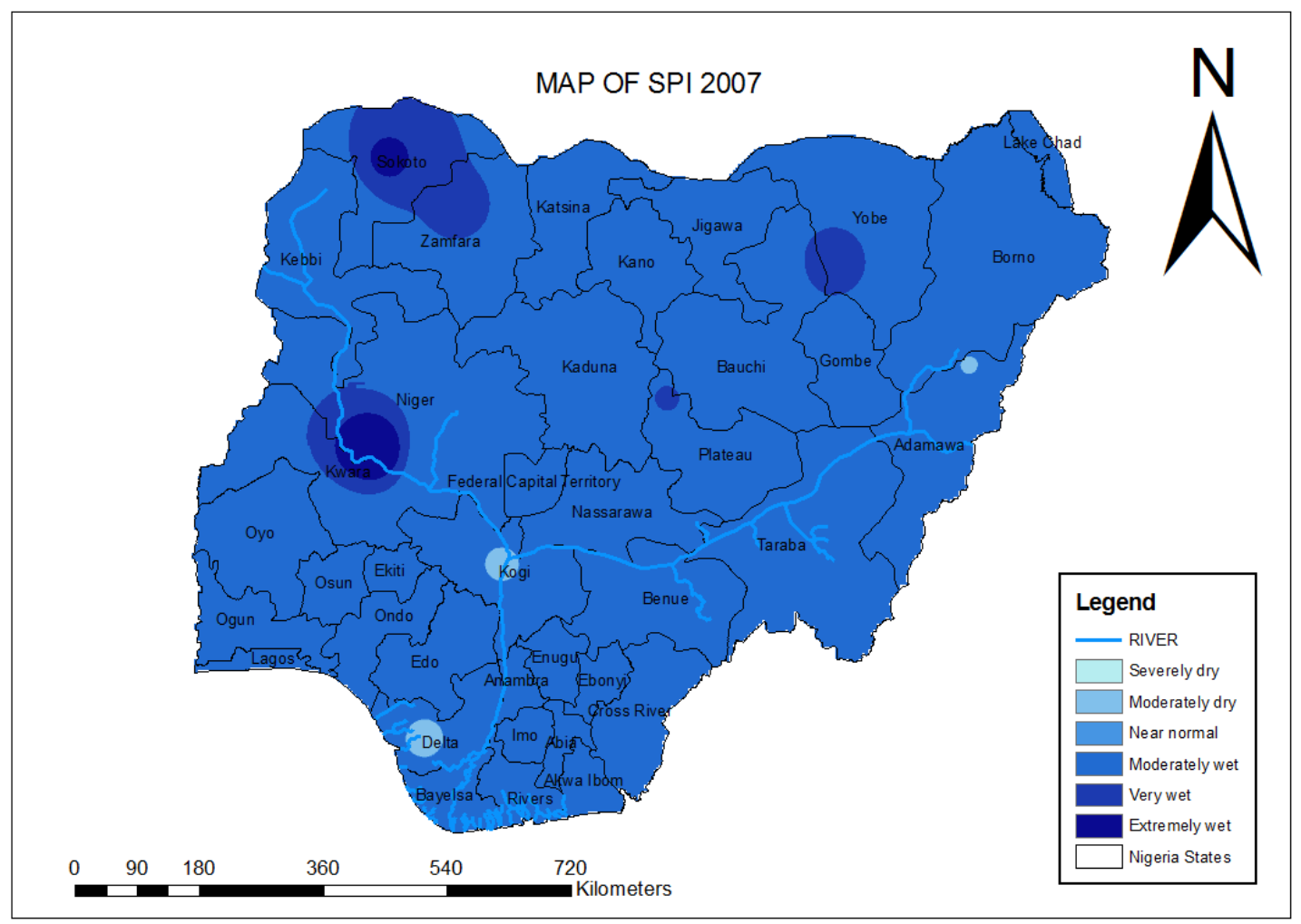

Fig. 1 (e) Map of SPI for 2007

Fig 1 (a) shows that in 1978, most places along the river Niger-Benue basin experienced the near normal condition except for Niger state that experiences the moderately and extremely wet conditions. Delta and Rivers state experience a near normal condition which means that the flood effect will not be much in these areas in this particular year. While Fig 1 (b) shows that in 1983, Kebbi state experience an extremely wet condition at the river mouth area that would trigger a flood that would travel downstream. Niger, Kogi, Kwara, Rivers and Benue state all experience a near normal condition in their respective coastal areas.

Fig. 1(c) shows that in 1995, all areas along the coast experience a moderately wet condition. While in Fig. 1 (d) shows that in 2004, a part of the coast of Kebbi state, the border between Niger and Kwara state and a part of Imo state experience a near normal condition. Another part of the coastal area of Niger state and Delta state experience a very wet condition signifying the occurrence of flood events in this area.

Fig. 1 (e) is for 2007, Kogi and Delta state coast experiences a near normal condition. The coastline along the border of Niger and Kwara state experiences an extremely wet condition which signifies a flood occurrence in these locations. All other coastal area experiences a moderately wet condition.

\section{Flow Direction and flow accumulation}

Fig. 2 shows the map of flow direction giving each cell a value according to North, Northeast, East, Southeast, South, Southwest, West, and Northwest reference. The direction of flow of river Niger and Benue can be seen on the map. 
A GIS-Based Flood Risk Mapping Along the Niger-Benue River Basin.................AKINBOBOLA et al.

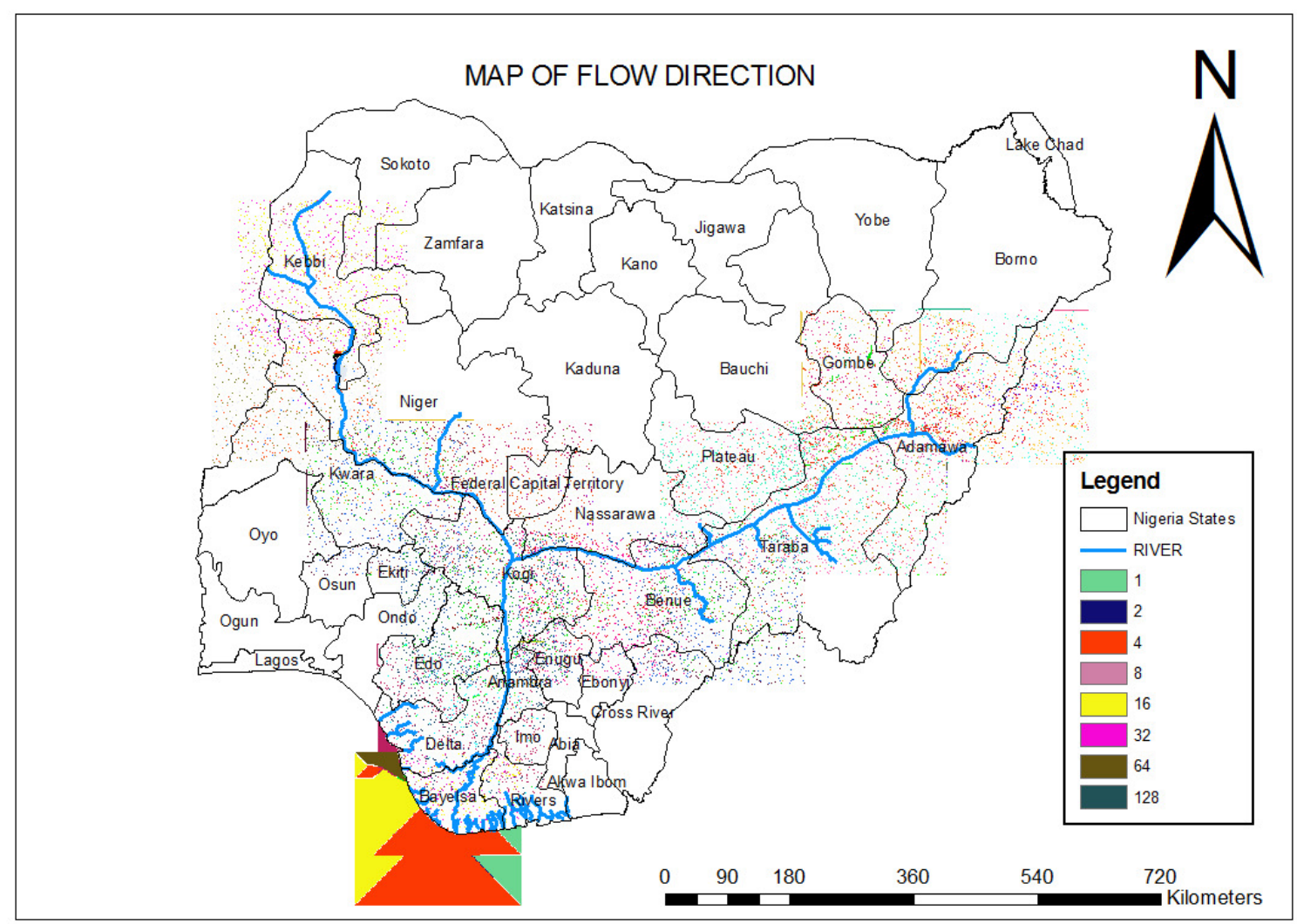

Fig. 2 Map of Flow Direction

Fig. 4 shows the stream network of river Niger and Benue. The main path and the tributaries that flow into the main path can be seen on the map. This is used to digitize the shapefile for river Niger and Benue. 
Ethiopian Journal of Environmental Studies and Management Vol. 8 no. 6, 2015

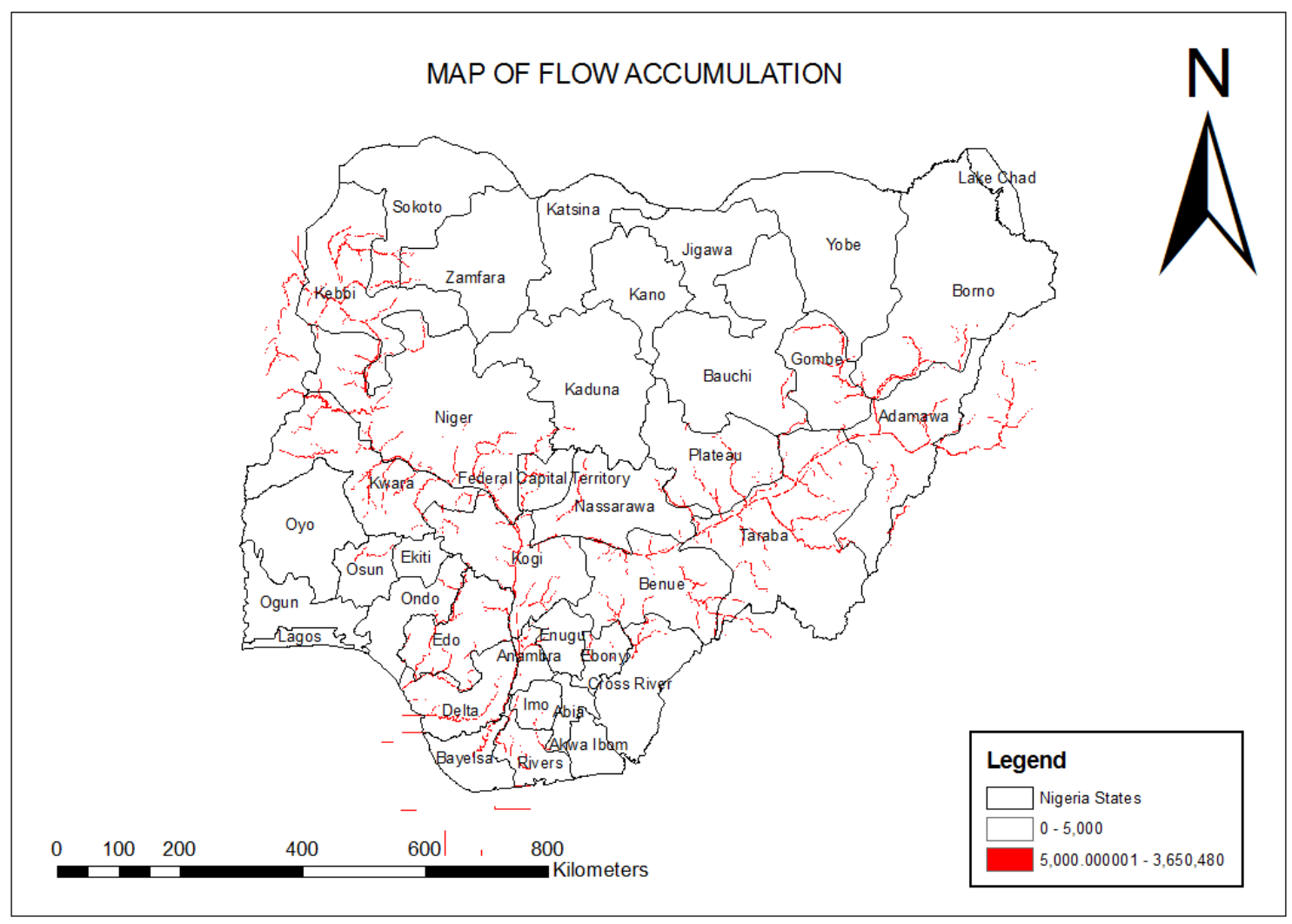

Fig. 4 Map of Flow Accumulation

\section{Watershed area along the coast of river Niger-Benue basin}

Fig. 5 shows the watershed area along the coast of river Niger-Benue basin. Towns and villages that falls within the watershed area are the locations that are at the risk of experiencing flood. 
A GIS-Based Flood Risk Mapping Along the Niger-Benue River Basin.................AKINBOBOLA et al.

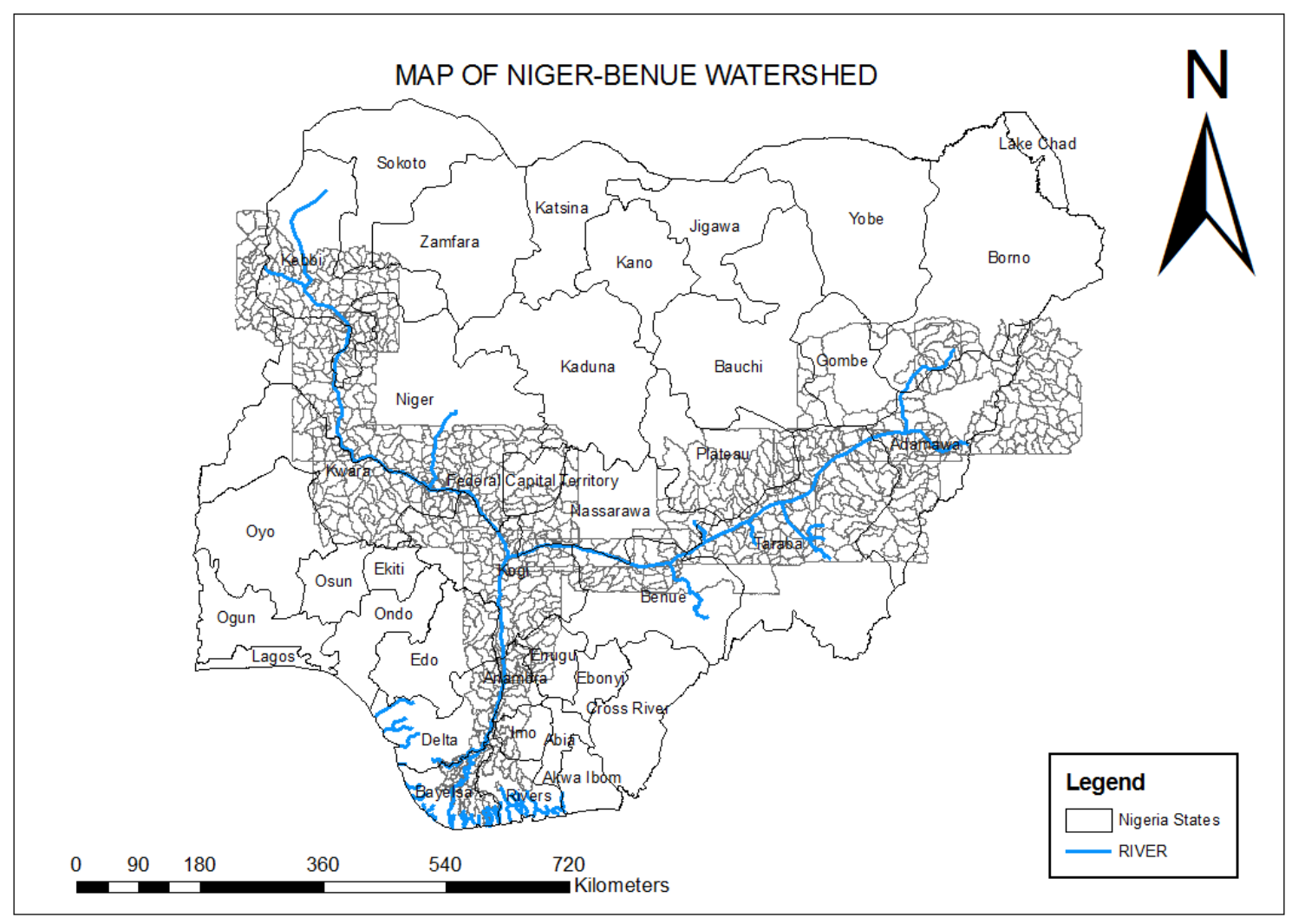

Fig. 5 Map of Watershed Area

\section{Flood risk map}

Fig. 6 shows the flood risk map. Towns and villages that are prone to flood are all in red dots. The number of towns and villages that falls within the watershed area of the river NigerBenue basin which is actually the flood plain is 19226 towns and villages. This is $45 \%$ of the whole towns and villages within the Nigerian boundary. The result shows that about half of the Nigerian populations settle on the flood plain of the river Niger and Benue basin. 


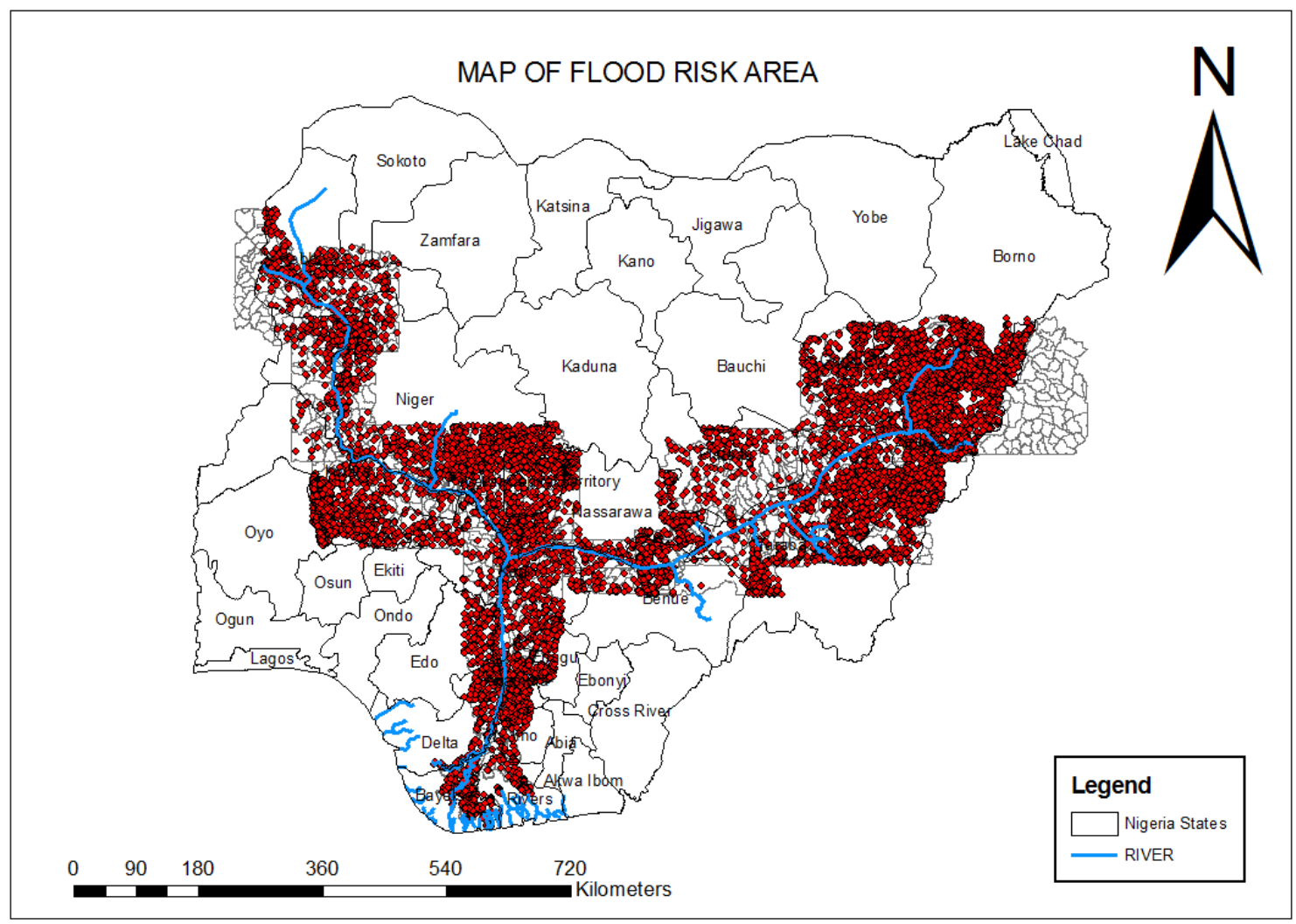

Fig. 6 Map of Locations prone to flood

\section{Conclusion}

This study has really highlighted the importance and usefulness of GIS in flood risk mapping and the ease of developing a flood risk maps for different ecological zones and urban areas in Nigeria using remote sensing data and GIS tool. Rainfall has been a major cause of flooding along the Niger-Benue River basin. The work shows that there are lots of towns and villages close to the bank of the river. Nigeria has been shown to be a country that experiences the moderately wet condition in most of its suburbs. Many lives and property are liable to be damaged by flood as long as people continue to live in these areas prone to flood. This damage will also affect the agricultural sector of Nigeria because there are many farms along the coast of the river Niger-Benue basin. Flood can lead to a complete wipe out of farm lands in this flood risk zones. The analysis shows that many people settled too close to the river banks. In some cases, it seems the settlement are even on the river path way.

The SRTM imageries were used to generate DEM (Digital Elevation Model) which was used also to get the flow direction, flow accumulation and watershed area of the river Niger-Benue basin. The towns and villages that falls within the watershed area are in the flood risk zone. The number of towns and villages in the flood risk zone was discovered to be about $45 \%$ of the towns and villages in Nigeria.

\section{References}

Adeoye, N.O., Ayanlade, A. and Babatimehin, O. (2009). "Climate change and menace of floods in 
Nigerian cities: socio-economic implications", Advances in Natural and Applied Sciences, 3(3): 369-377.

Aljazeera (2011). Africa: Flooding Leaves 102 Dead in South West Nigeria, available at http://english.aljazeera.net/news/africa /2011/08/201183162253653316.html, last assessed October 25, 2011.

CBS News World (2010). Nigeria Flooding Displaces 2 Million People, available at

http://www.cbsnews.com/stories/2010 /09/24/world/main6898503.shtml, last assessed October 25, 2011.

National Aeronautics and Space Administration (NASA) (2011c). Landsat 7 ETM+, available at http://landsat.gsfc.nasa.gov/about/land sat7.html, last assessed November 2, 2011

Mukhtar, A.B (2011). "Poor drainages caused Kano flooding - NEMA", Daily Trust, available at http://dailytrust.com.ng/index.php?opt ion $=$ com_content $\&$ view $=$ article \&id $=2$ 1831:poordrainages-caused-kano-

flooding-nema\&catid $=1$ :news\&Itemid $=2, \quad$ last assessed October 25, 2011.

Nmeribeh, M. (2011). "Kano's flood disaster", TheNEWS, available at http://thenewsafrica.com/2011/06/27/k ano\%E2\%80\%99s-flood-disaster/, last assessed October 25, 2011. 